\title{
横荷重下における FRP 積層構造の損傷進展予測*1 Prediction of Damage Extension in Laminated Structures under Transverse Loads
}

\author{
前場 豊*2. 胡 寧*2. 福 永久 雄*2 \\ Yutaka Zemba, Ning Hu and Hisao Fukunaga
}

Key Words : Cohesive Interface Model, Laminate, Delamination, Finite Element Analysis

\begin{abstract}
In this paper, to deal with the complex damage propagations in various composite structures under quasi-static transverse loads, a numerical simulation methodology based on the three-dimensional (3D) finite element method is proposed. In this numerical model, two categories of damage patterns existing in composite structures under transverse loads are tackled independently. First, a stress-based criterion is adopted to deal with the first category, i.e. various in-plane damages, such as fiber breakage, transverse matrix cracking etc. Second, a bi-linear cohesive interface model is employed to deal with the second category, i.e., interface damages, such as delaminations. Also, to remove the numerical instability when using the cohesive model, we propose a simple and useful technique, where the move-limit in the cohesive zone is built up to restrict the displacement increments of nodes in the cohesive zone after the occurring of delaminations. This numerical model is further applied to various composite structures, such as $2 \mathrm{D}$ laminated plates and 3D laminated shells under the transverse loads. A lot of information is provided for understanding the propagation mechanisms of various damages in composite structures.
\end{abstract}

1. 緒言

繊維強化複合材料 (FRP) の損傷には繊維破断，マトリッ クスクラック，マトリックス圧縮破壞などの面内破壊と層 間はく離があり，これらの破壞を予測するために従来から 数多くの研究が行われている. 例えば面内破壞については Chang-Chang 応力破壞基準1) が広く知られている.この 破壊基準では面内方向に働く応力によって損傷の有無を判 定するため, 板厚が十分に薄くない場合など面外方向の応 カが大きい場合は光の影響を正しく評価できない，乥こで Hou ら ${ }^{2)}$ は, 面内破壞に対して板厚方向に衝くせん断力も 考慮した新しい破壊基準を提案している。

主要な損傷パターンである層間はく離については Brewer と Lagace $^{3)}$ は層間はく離の応力破壞基準を提案している が，Davies と Zhang ${ }^{4)}$ は，応力破壞基準でははく離の開 始は予測できるが，はく離サイズを正しく予測することは 困難であるとしている．一方でKamiya ら ${ }^{5)}$ は，各層を二 次元平板でモデル化しき裂先端のエネルギー解放率を見積 もり，これか限界値を超えた場合に層間の拘束を解放する ことによって平板のはく離形状をシミュレーションする方 法を提案している .この方法ではき裂先端前後の応力とひ ずみ分布の差を利用してエネルギ一解放率を見積もるため， 初期はく離の設定が重要となる .

\footnotetext{
*1 (C) 2006 日本航空宇宙学会

平成 17 年 10 月 11 日原稿受理

*2 東北大学大学院工学研究科航空宇宙工学専攻
}

層間はく離の進展を予測する別の方法として，層間のイ ンターフェースに結合力のあるコヒーシブ要素 (Cohesive Element) を用いる手法が広く研究されている ${ }^{6}$. この要素 の最大の特徵は, 初期はく離の位置やはく離伝播方向があ らかじめ分からない場合でもはく離の開始や伝播を予測可 能なことにあるが，しばしば数值的な不安定現象が生じる ことも分かっている ${ }^{7,8)}$. コヒーシブ要素は大きく分けて層 間にバネ要素を配置するモデルとソリッド要素を配置する モデルがあり，間島と末益9,10) はソリッド要素を用いる方 が要素サイズが大きくてもより安定した解析が可能である ことを示している．また，Gao と Bower ${ }^{11)}$ ははく離時の 解放エネルギーを消散するために陰解法に一種の人工減衰 を導入し，解析の安定化をはかっている.

一方で , この不安定性はコヒーシブ要素の剛性がはく離 によって急落し, 少ない外力増加に対して極めて大きな変位 増加を招いて計算が発散してしまうことが要因であるため， 岡性の急落を避けるために低いコヒーシブ要素剛性や層間 強度を用いることで不安定性を軽減することができる ${ }^{8)}$. し かし，低すぎる剛性や層間強度ははく離が始まる前からコ ヒーシブ要素の軟化の影響が大きく現れ，初期勾配に誤差 を生じやすい.さらに，これまでの多くの研究でメッシュ サイズを細かくすると滑らかな損傷進展解析が可能である ことも分かっているが7), 細かい要素サイズは計算コスト を増大させることになる 。

これらの背景により，従来の研究では DCB や二次元問 題での検討例が多く，三次元要素を用いたモデルや，渋維 
破断，マトリックスクラック，マトリックス圧縮破壊，層間 はく離を同時に考慮した計算例はまだ少ない .㫕こで，本 研究ではすべての破壊モードを考慮し，計算コストを増大 させることなく安定した損傷進展解析が可能な, 三次元要 素を用いた解析モデルを提案する．纎維破断，マトリック スクラック , マトリックス圧縮破壊などの面内破壞について は応力破壊基準を用い，これらの面内破壊によって計算が 不安定にならないための適用手法を示す. また，特に不安 定性の主要因となる層間はく離については, 既に著者ら ${ }^{12)}$ は DCB モデルについて要素サイズやコヒーシブ要素の材 料特性か数值不安定性に与える影響を示し，はく離先端の コヒーシブ要素に対し Gao ら ${ }^{11)}$ の減衰効果を陽解法に拡 張した手法と，急激な変位増加に対して変位抑制効果を導 入し数值安定化をはかる手法を提案し，特に変位抑制効果 に基づく手法は損傷の進展を妨げることなく高い数值安定 性を示すことを明らかにした .

本研究では, 前報12) でモード I のはく離進展問題に適 用した变位抑制効果に基づく手法を，モード I〜III の混合 モードでのはく離進展問題に拡張して不安定性の低減に有 効であることを示す .この解析モデルを板やシェルといっ た代表的な構造に適用して，面内破壊と層間はく離が同時 に作用する複杂倠な損傷進展を予測する。

\section{2. 解 析 手 法}

2.1 有限要素法 損傷進展のシミュレーションには二 ユートン・ラプソン法を用いた陰解法よりも非平衡力の繰り 返し計算が不要な中央差分法が広く用いられており ${ }^{13 \sim 15)}$, 本論文でも光れを採用する．定式化した運動方程式は次式 で与えられる。

$$
\boldsymbol{M} \ddot{\boldsymbol{u}}_{n}+\boldsymbol{C} \dot{\boldsymbol{u}}_{n}+\boldsymbol{p}_{n}=\boldsymbol{f}_{n}
$$

ここで $M$ は質量マトリックス， $C$ は減衰マトリックス， $\boldsymbol{P}_{n}$ は内力, $\boldsymbol{f}_{n}$ は外力である . また，変位べクトルは次式 で与えられる .

$$
\begin{aligned}
\boldsymbol{u}_{n+1}= & \left(\boldsymbol{M}+\frac{\Delta t}{2} \boldsymbol{C}\right)^{-1}\left[(\Delta t)^{2}\left(-\boldsymbol{p}_{n}+\boldsymbol{f}_{n}\right)\right. \\
& \left.+2 \boldsymbol{M} \boldsymbol{u}_{n}-\left(\boldsymbol{M}-\frac{\Delta t}{2} \boldsymbol{C}\right) \boldsymbol{u}_{n-1}\right]
\end{aligned}
$$

また，内力は次式で表される．

$$
\boldsymbol{p}_{n}=\sum_{i=1}^{N E} \boldsymbol{k}_{n}^{i}\left(\boldsymbol{u}_{n}^{i}\right) \boldsymbol{u}_{n}^{i}
$$

$N E$ は全要素数, $\boldsymbol{k}_{n}^{i}$ は $n$ ステップにおける各要素の岡性 マトリックスであり, 損傷の進展によってコヒーシブ要素 の岡性マトリックスが更新される .

中央差分法は繰り返し計算が不要であるという利点があ るが, 時間ステップを小さく刻まなければならないため計 算時間が増大する欠点がある. 本研究で取り扱う損傷解析 は準静的な問題であるので, 損傷が生じるまでは静的解析

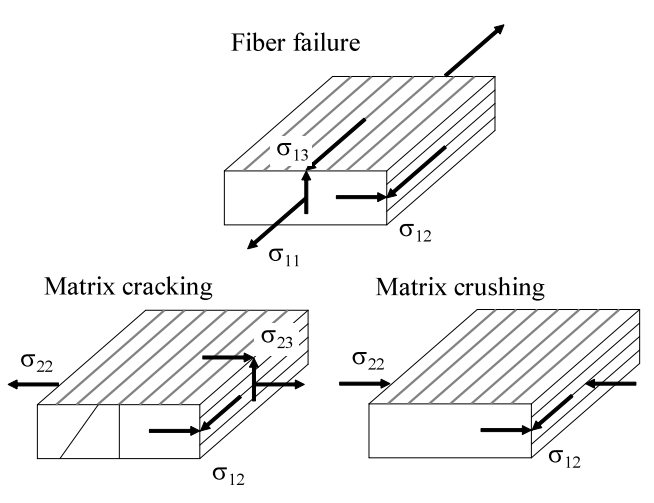

第 1 図 面内破壞モード

を行い, 弚の後中央差分に切り替えることとする . 要素に ついては，メッシュの分割形状に依存しにくく，大变形解 析にも有効である Hu-Washizu 理論に基づいた三次元の変 位・応力のハイブリッド要素を用いる16).

2.2 面内破壊基準 繊維破断, マトリックスクラック, マトリックス圧縮破壊については第 1 図に示す Hou ら²) の 応力破壊基準を適用する . 本論文では , 要素の各積分点に おいて下式の条件を満たすときに損傷が進展したものとし て材料定数を低減する．ただし，三次元要素の厚みがゼロ となって大変形解析が不安定にならないように厚み方向の 岡性の低減は行わない．また，一度面内破壊を生じた点に 対して，圧縮応力下では樹脂の岡性が残るものとした . 各 面内破壞モードの判定基準を下式に示す．

·繊維破断の場合 :

$$
e_{\mathrm{f}}^{2}=\left(\frac{\sigma_{11}}{X_{\mathrm{T}}}\right)^{2}+\left(\frac{\sigma_{12}^{2}+\sigma_{13}^{2}}{S_{\mathrm{f}}^{2}}\right)^{2} \geq 1
$$

のとき，材料定数を下式のように更新する .

$$
\begin{aligned}
& E_{1}=E_{\min }, \quad\left(\text { if } \sigma_{11} \text { is tensional stress }\right) \\
& E_{1}=E_{\text {polymer }}, \quad\left(\text { if } \sigma_{11} \text { is compressive stress }\right) \\
& E_{2}=E_{\min } \\
& \nu_{i j}=\nu_{\min }(i, j=1,2,3) \\
& \text { ・マトリックスクラックの場合 }\left(\sigma_{22} \geq 0\right): \\
& e_{\mathrm{mc}}^{2}=\left(\frac{\sigma_{22}}{Y_{\mathrm{T}}}\right)^{2}+\left(\frac{\sigma_{12}}{S_{12}}\right)^{2}+\left(\frac{\sigma_{23}}{S_{\mathrm{m} 23}}\right)^{2} \geq 1
\end{aligned}
$$

のとき，材料定数を下式のように更新する .

$$
\begin{aligned}
& E_{2}=E_{\min }, \quad\left(\text { if } \sigma_{22} \text { is tensional stress }\right) \\
& E_{2}=E_{\text {polymer }}, \quad\left(\text { if } \sigma_{22} \text { is compressive stress }\right) \quad(7) \\
& \nu_{12}=\nu_{\min } \\
& G_{12}=G_{\min }
\end{aligned}
$$

・マトリックス圧縮破壊の場合 $\left(\sigma_{22}<0\right)$ :

$$
e_{\mathrm{mr}}^{2}=\frac{1}{4}\left(\frac{\sigma_{22}}{S_{12}}\right)^{2}+\frac{Y_{\mathrm{C}}^{2} \sigma_{22}}{4 S_{12}^{2} Y_{\mathrm{C}}}-\frac{\sigma_{22}}{Y_{\mathrm{C}}}+\left(\frac{\sigma_{12}}{S_{12}}\right)^{2} \geq 1
$$


のとき，材料定数を下式のように更新する .

$E_{2}=E_{\min }, \quad$ (if $\sigma_{22}$ is tensional stress)

$E_{2}=E_{\text {polymer }}$, (if $\sigma_{22}$ is compressive stress) (9)

$\nu_{12}=\nu_{\min }$

ここで，

$e_{\mathrm{f}}:$ 纎維破断の破壞判定パラメータ

$e_{\mathrm{mc}}$ : マトリックスクラックの破壞判定パラメータ

$e_{\mathrm{mr}}$ : マトリックス圧縮破壊の破壞判定パラメータ

$X_{\mathrm{T}}$ : 繊維方向引張強度

$Y_{\mathrm{T}}:$ 繊維直角方向の引張強度

$Y_{\mathrm{C}}:$ 繊維直角方向の圧縮強度

$S_{12}:$ 渋維方向-䋐維直角方向のせん断強度

$S_{\mathrm{f}}:$ 繊維破断を伴うせん断強度

$S_{\mathrm{m} 23}$ : マトリックスクラックに対する厚さ方向一厚さ直角 方向のせん断強度

$E_{\min }, G_{\min }, v_{\min }$ は各破壞モードで損傷したと判定され た場合に更新される材料定数であり，適当に小さな値をと る. $E_{\text {polymer }}$ は一度面内破壊と判定された要素が圧縮応力 下にある場合に用いられる樹脂の岡性である . 本論文では $E_{\text {min }}=10.0 \mathrm{MPa}, G_{\text {min }}=5.0 \mathrm{MPa}, v_{\text {min }}=1.0 \times 10^{-6}$, $E_{\text {polymer }}=3.0 \mathrm{GPa}$ としたが , 著者らの計算によると多少 異なる值を用いても計算結果に与える影響は小さい．

また，1つの時間ステップで多くの点が一度に (4) 式，(6) 式，(8) 式を満たす場合, 広い範囲で急激に風性が低下す るため数値不安定を引き起こす可能性がある. 乥こで, 数 值不安定を避けるため以下の条件を考慮する．今，1つの 時間ステップ内における全積分点での破壞判定パラメータ の最大值を下式のように定義する .

$$
\begin{aligned}
& e_{\mathrm{f}}^{\max }=\max \left\{e_{\mathrm{f}}^{i}\right\}, \quad e_{\mathrm{mc}}^{\max }=\max \left\{e_{\mathrm{mc}}^{i}\right\}, \\
& e_{\mathrm{mr}}^{\max }=\max \left\{e_{\mathrm{mr}}^{i}\right\}
\end{aligned}
$$

ここで $i=1 \sim N G I, N G I$ は全要素の全積分点数であり， 既に破壞した点は除く. 次に，全積分点の中で破壊判定パ ラメータの高い積分点を下式により抽出する．

$$
\begin{aligned}
& e_{\mathrm{f}}^{i}>1.0 \text { and }\left(e_{\mathrm{f}}^{i}-1.0\right) /\left(e_{\mathrm{f}}^{\max }-1.0\right)>(1.0-d e) \\
& e_{\mathrm{mc}}^{i}>1.0 \text { and }\left(e_{\mathrm{mc}}^{i}-1.0\right) /\left(e_{\mathrm{mc}}^{\max }-1.0\right)>(1.0-d e) \\
& e_{\mathrm{mr}}^{i}>1.0 \text { and }\left(e_{\mathrm{mr}}^{i}-1.0\right) /\left(e_{\mathrm{mr}}^{\max }-1.0\right)>(1.0-d e)
\end{aligned}
$$

ここで, de は面内破壞とみなす範囲を定める定数で, 本論 文では 0.3 とした . (11) 式はある時間ステップで最も破壞 の可能性が高い点及び光の de の範囲にある点 (本論文で は最大破壊判定パラメータから $30 \%$ の範囲にある点) の剛 性だけをまず低下させ , 次の時間ステップで応力の再分配 を考慮するためのものである . また中央差分法においては $\omega_{\max }$ を損傷前の最大角振動数とすると, 時間ステップは $\Delta t=2 / \omega_{\max }$ で与えられ，一般に $1 \times 10^{-7} \mathrm{sec}$ 以下と極 めて小さい、従って破壤判定パラメータが 1 を越えたにも

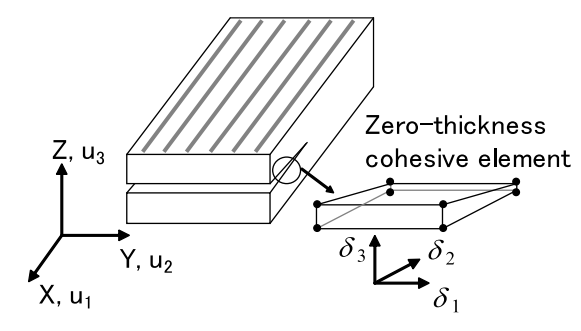

第 2 図コヒーシブ要素

かかわらず (11) 式によって損傷を除外された点について も，次の時間ステップで応力を再分配され再度損傷の判定 が行われるので, 面内破壞の進展を阻害する可能性は小さ い.これによって，すべての積分点で同時に破壞し計算が 中断するという現象を防ぐとともに面内破壊進展中の応力 の再分配を考慮することができ，安定かつ精度よく面内破 壊をシミュレーションできる．

2.3 コヒーシブ要素 層間はく離をシミュレーションす るために , 第 2 図に示すような層間に初期厚さゼ口の 8 節 点コヒーシブ要素を配置し，はく離進展とともに剛性を低 下させるモデルを用いる ${ }^{6)}$.このコヒーシブ要素の構成方 程式は層間に生ずる変位と伝達荷重の関係から導かれ，以 下のように考える .

変形の全くない状態から荷重を負荷すると, 初期厚さが ゼロであったコヒーシブ要素に変形が生じる .このときコ ヒーシブ要素内の上面・下面の相対変位を水平面内に分解 した变位を $\delta_{1}, \delta_{2}$ ，光れに直交する方向に分解した变位を $\delta_{3}$ とすると, $\delta_{3}$ はモードI 方向の開口変位, $\delta_{2}, \delta_{1}$ はモ一 ド II , III 方向の変位を表す（これらを有効変位と呼心゙）. また，モードが混合している状態での有効変位は次式で表 される .

$$
\delta_{\mathrm{m}}=\sqrt{\delta_{1}^{2}+\delta_{2}^{2}+\left\langle\delta_{3}\right\rangle^{2}}
$$

ここで，

$$
\langle x\rangle=\left\{\begin{array}{l}
0 \Leftarrow x \leq 0 \\
x \Leftarrow x>0
\end{array}\right.
$$

また，はく離による破壊パラメータ $d$ を下式のように定義 する

$$
d=\frac{\delta_{\mathrm{m}}^{\mathrm{f}}\left(\delta_{\mathrm{m}}^{\max }-\delta_{\mathrm{m}}^{0}\right)}{\delta_{\mathrm{m}}^{\max }\left(\delta_{\mathrm{m}}^{\mathrm{f}}-\delta_{\mathrm{m}}^{0}\right)}, \quad d \in[0,1]
$$

ここで, $\delta_{\mathrm{m}}^{\max }$ は時間経路上の最大の混合モ一ド有効変位， $\delta_{\mathrm{m}}^{0}$ は軟化か始まる有効変位, $\delta_{\mathrm{m}}^{\mathrm{f}}$ は完全にはく離する有効 変位で, 乥れ芘れモードI〜モード III の層間強度 $N, S$, $T$ と破壞䩛性 $G_{\mathrm{IC}} \sim G_{\mathrm{IIIC}}$ ，及び初期剛性を表すパラメー タ $K$ によって決まる值である.コヒーシブ要素の特性は，

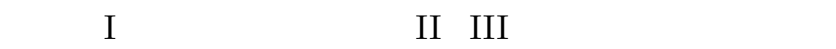
第 3 图に示すような双一次の関係がある . 混合モードにお けるコヒーシブ要素の剛性 $\boldsymbol{k}$ は，ひずみ-変位マトリック ス $\boldsymbol{B}$ ，応力ーひずみマトリックス $\boldsymbol{D}$, 光の成分を $D_{i j}$ とす 
ると下式で表される .

$$
\begin{aligned}
& \boldsymbol{k}= \boldsymbol{B}^{\mathrm{T}} \boldsymbol{D} \boldsymbol{B} \mathrm{d} \Gamma \\
& D_{i j}= \begin{cases}\bar{\delta}_{i j} K & \left(\delta_{\mathrm{m}}^{\max } \leq \delta_{\mathrm{m}}^{0}\right) \\
\bar{\delta}_{i j}[(1-d) K & \left.K d \bar{\delta}_{i 3} \frac{\left\langle-\delta_{3}\right\rangle}{-\delta_{3}}\right] \\
\bar{\delta}_{i 3} \bar{\delta}_{3 j} \frac{\left\langle-\delta_{3}\right\rangle}{-\delta_{3}} K & \left(\delta_{\mathrm{m}}^{0}<\delta_{\mathrm{m}}^{\max }<\delta_{\mathrm{m}}^{\mathrm{f}}\right)\end{cases}
\end{aligned}
$$

$\bar{\delta}_{i j}:$ Kronecker delta for $(i, j=1 \sim 3)$

2.4 変位抑制による数值不安定の軽減 はく離進展時 に数值不安定になるとき, はく離進展とともにコヒーシブ 要素の岡性が急速に低下して伝達荷重が突然解放されるこ とにより，コヒーシブ要素の節点が急激に変位する．兰こ でこの急激な節点变位を抑制することて数值不安定を防ぐ 簡単にモードIにおける変位抑制モデルを第 4 図に示す .コ ヒーシブ要素の節点が図に示す固定壁を越える場合は強制 的に節点を固定壁まで戻すこととし，この固定壁の幅の半 分 $Q^{i}$ は下式のように定義する.

$$
Q^{i}=\alpha V_{\mathrm{L}} \Delta t
$$

ここで, $i$ は 3 つの軸方向を示し， $V_{\mathrm{L}}$ は荷重条件として与 えた節点の変位速度である。 $\alpha$ は変位制限幅を制御する変 位抑制パラメータである。なお，既に完全にはく離したコ ヒーシブ要素については固定壁を設定しない .

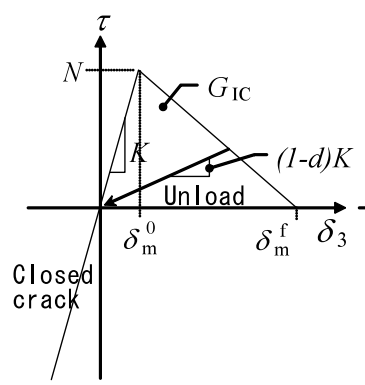

(a) Mode I

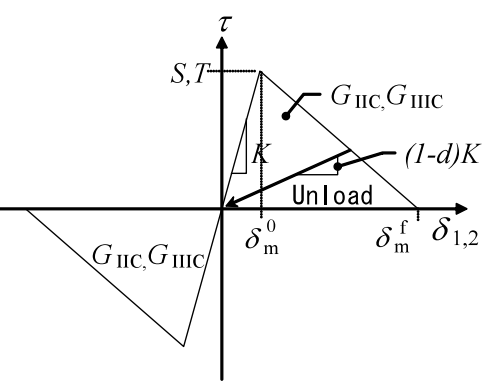

(b) Mode II, Mode III

\section{第3図 コヒーシブ要素の材料特性}

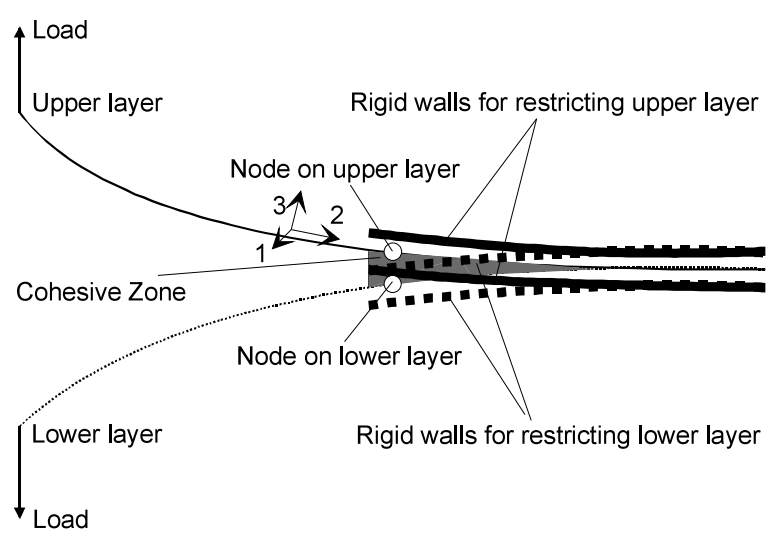

第 4 図 变位抑制効果
また, 計算が安定する条件は 1 つの時間ステップで外力 のなす仕事がコヒーシブ要素で解放されるエネルギーより 大きい場合であり，これを定式化すると次式となる．

$$
\sum_{i=1}^{N F} F_{i} V_{\mathrm{L}} \Delta t \geq \sum_{i=1}^{N E C}\left(\frac{1}{2} \Delta u_{1}^{2} K+\frac{1}{2} \Delta u_{2}^{2} K+\frac{1}{2} \Delta u_{3}^{2} K\right) A_{i}
$$

ここで, $K$ はコヒーシブ要素の岡性パラメータ, $F_{i}$ は外力 , $\Delta u_{i}$ は 1 つの時間ステップでのコヒーシブ要素の各節点の 変位量,$N F$ は外力を加えた節点の総数で, $N E C$ はコヒー シブ要素の総数である. 簡単のため 3 つの方向の相対变位 が同一である場合を考えると，

$$
\Delta u=\Delta u_{1}=\Delta u_{2}=\Delta u_{3}
$$

さらに, コヒーシブ要素の上下面の絶対変位が符号対称で 同一であると仮定し，光の量の絶対值を $\Delta u_{\mathrm{c}}=\alpha V_{\mathrm{L}} \Delta t$ と すると，

$$
\Delta u=2 \Delta u_{\mathrm{c}}=2 \alpha V_{\mathrm{L}} \Delta t
$$

となる.$(17) \sim(19)$ 式より， $\alpha$ は次式のように定義できる .

$$
\alpha=\frac{\sqrt{\sum_{i=1}^{N F} F_{i} V_{\mathrm{L}} \Delta t / \sum_{i=1}^{N E} 6 K A_{i}}}{V_{\mathrm{L}} \Delta t}
$$

なお上記て畄いた $\alpha$ においては , 現在の時間ステップ内 における構造のひずみエネルギーと運動エネルギーの増分 の影響は小さいものとして無視している .

(20) 式で定めた変位抑制幅は, 数值不安定時の物理的に 意味を持たない急激な変位増加を抑制しつつ，かつ，はく 離進展による变位増加に対しては何ら拘束しない効果を持 つ. 本手法が十分な数值安定効果を発揮できるとともに , は く離進展を妨げないことについては文献 12) にて検証して いる。

\section{3. 板の計算結果}

第 5 図に示す板を対象に，数値計算と文献 5) の実験 值との比較を行う. $90 \mathrm{~mm} \times 90 \mathrm{~mm}$ の GFRP 積層板， $\left[0_{10} / 90_{10}\right]_{\mathrm{S}}$ の単純支持板に集中荷重を載荷した . 解析モデ ルは対称性を考慮し $1 / 4$ モデルとした．また，集中荷重は 貫通を防ぐため中央 $0.5 \mathrm{~mm}$ 角の範囲で載荷する.要素サイ

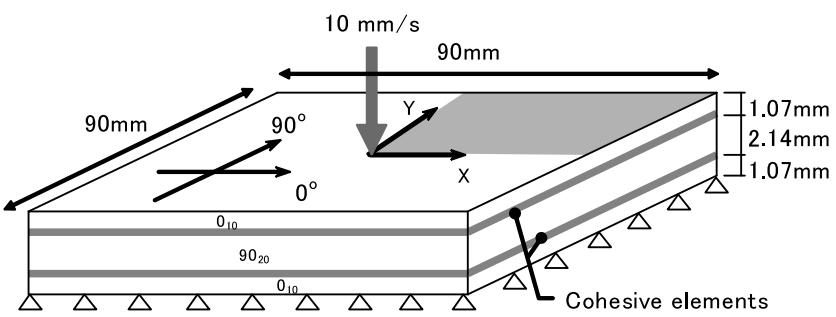

第 5 図 GFRP 板解析モデル 
ズは荷重点近傍で $0.5 \mathrm{~mm} \times 0.5 \mathrm{~mm}$, 中央部から $35 \mathrm{~mm}$ 角の範囲は $2.0 \mathrm{~mm} \times 2.0 \mathrm{~mm}$, 兴の外側は $5 \mathrm{~mm}$ 刻み, 厚 さ方向には各層で 1 分割である.積層材の弾性定数，及びコ ヒーシブ要素の材料定数, 面内破壞パラメータは第 1 表に 示す. 弾性定数については初期勾配を実験值 ${ }^{5}$ と整合させる ため多少の調整を行っている.コヒーシブ要素の破壊勒性に ついては文献 5) の解析で使用した混合モ一ドのエネルギー 解放率は $G_{\mathrm{C}}=0.4 \mathrm{~kJ} / \mathrm{m}^{2}$ であり，また過去の研究 ${ }^{17,18)}$ から得られている $0.2 \sim 0.9 \mathrm{~kJ} / \mathrm{m}^{2}$ という值を考慮し, 本計 算例では $G_{\mathrm{IC}}=0.2 \mathrm{~kJ} / \mathrm{m}^{2}, G_{\mathrm{IIC}}=G_{\mathrm{IIIC}}=0.6 \mathrm{~kJ} / \mathrm{m}^{2}$ とした . モード I〜III の層間強度7) は $N=20.0 \mathrm{MPa}$ ， $S=T=35.5 \mathrm{MPa}$ とし, 面内破壞パラメータは Hou ら の文献2) の值を引用したが，纎維破断に関係するパラメー タ $X_{\mathrm{T}}, S_{\mathrm{f}}$ についてのみ, 本モデルの材質が GFRP であ ることを考慮して調整を行っている。

荷重点の変位と荷重の関係を実験值 ${ }^{5}$ とともに第 6 図に 示す．まず，荷重が $1200 \mathrm{~N}$ のとき荷重点直下に小さい繊維 破断が発生し荷重が若干低下する (A 点). 弚れとともに荷 重点側の層間及び荷重反対側の層間に小さいはく離が発生

第 1 表 GFRP 板モデルの材料特性
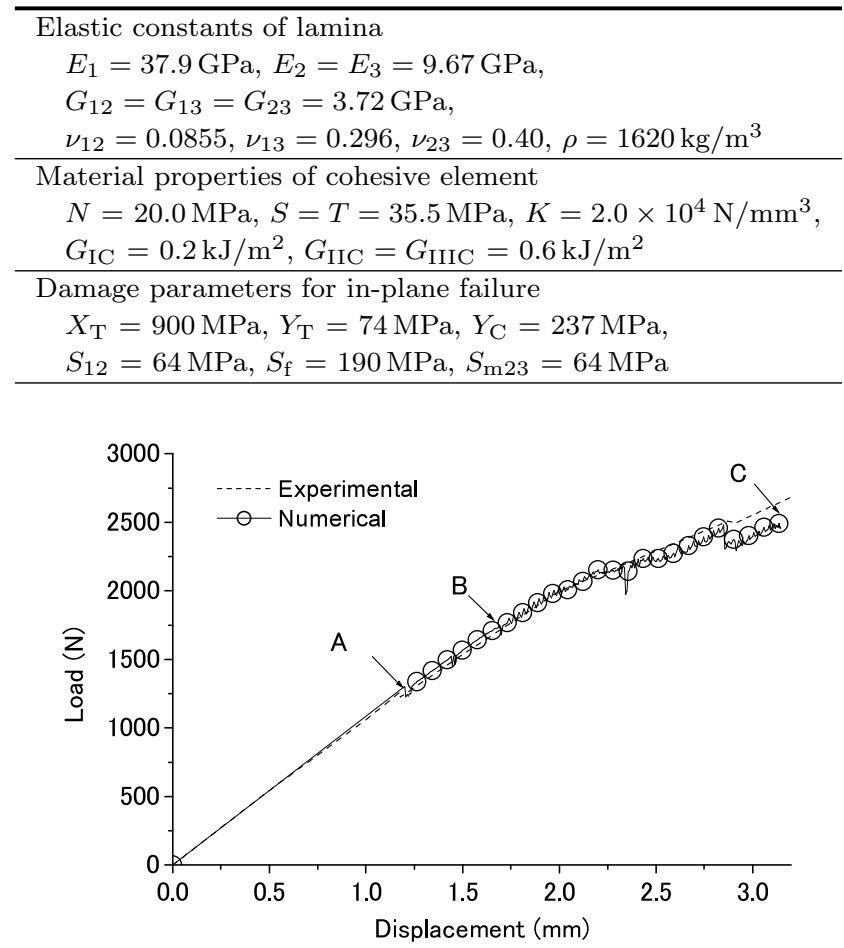

(a) 荷重履歴

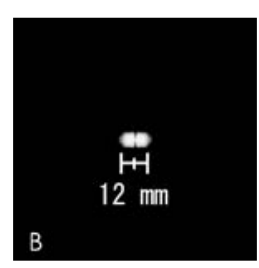

$\mathrm{B}$ 点解析結果

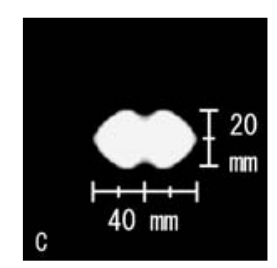

$\mathrm{C}$ 点解析結果

(b) はく離形状

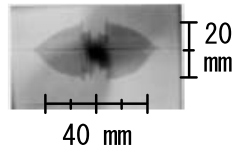

実験結果（2500N）
第 6 図 GFRP 板解析結果
する．続いて，荷重点反対側の層にマトリックスき裂が繊 維方向に沿って進展すると同時にゆっくりとコヒーシブ要 素の軟化領域が大きくなるが, 完全にはく離する領域が発 生するまでははく離・軟化ともに急速に広がることはない . 荷重が $2000 \mathrm{~N}$ に達すると，すでに軟化した領域の中で完 全にはく離する部分が発生し, 弚の後は比較的速くはく離 領域が広がることによって荷重勾配もさらに緩やかになる． はく離形状について, 図中 B 点では荷重反対側において約 $1 \mathrm{~cm}$ 程度の小さなはく離が発生し, 弚の後はく離は徐々に 速く進展していく. 荷重 $2500 \mathrm{~N}$ 付近の $\mathrm{C}$ 点ではピーナッ ツ状のはく離が 0 度方向に約 $4 \mathrm{~cm}, 90$ 度方向に約 $2 \mathrm{~cm}$ ま で広がっており，実験値 ${ }^{5)}$ とほぼ一致する．

この結果から，変位抑制効果による数值安定化手法はモ一 ド I〜III のはく離が混合するような場合でも適用できるこ とが分かり, また本解析で用いた面内破壊とはく離を考慮 した解析モデルが妥当であることが分かる .

\section{4. シェルの計算結果}

4.1 分布荷重下におけるシェルの損傷進展 第 7 図に示 す CFRP 円筒に分布荷重を載荷したモデルを対象に, 数値 計算と実験値 ${ }^{19)}$ との比較を行う. 積層構成は第 2 表に示す Case 1〜3の $\left[15_{9} /-15_{9}\right]_{\mathrm{S}},\left[30_{9} /-30_{9}\right]_{\mathrm{S}},\left[45_{9} /-45_{9}\right]_{\mathrm{S}}$ とし, 要素は円周方向に全周 200 分割, 長手方向に 2 分割, 厚さ方向には各層で 1 分割である. 材料は T300/\#2500 と して各材料定数を第 3 表に示す.コヒーシブ要素の破壊鞄性 $G_{\mathrm{IC}} \sim G_{\mathrm{IIIC}}$ は板と同樣の值を使用するものとし，面内破 壊パラメータについては文献 2) にある CFRP の值とした . 荷重点の変位と荷重の関係を実験值 ${ }^{19)}$ とともに第 8 図に

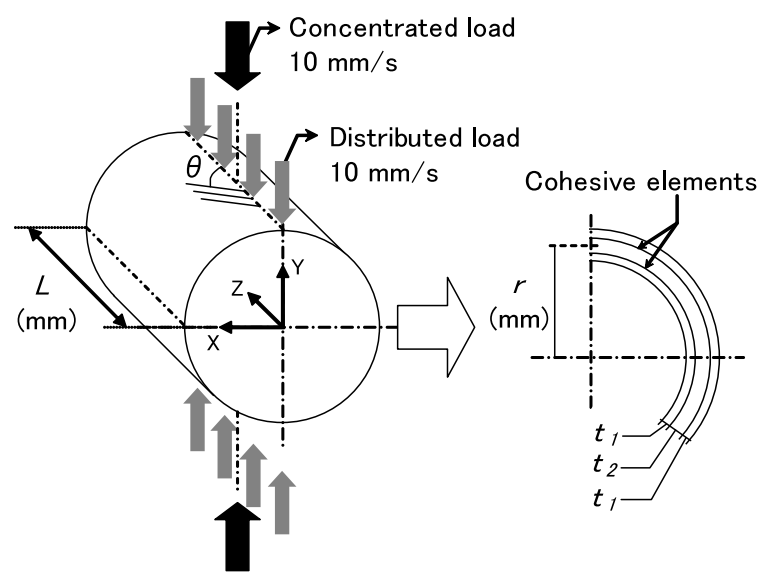

第7図 CFRP シェル解析モデル

第 2 表 積層構成と荷重条件

\begin{tabular}{ccccccc}
\hline $\begin{array}{c}\text { Case } \\
\text { No. }\end{array}$ & $\begin{array}{c}\text { Fiber } \\
\text { angle }\end{array}$ & $\begin{array}{c}\text { Load } \\
\text { type }\end{array}$ & $\begin{array}{c}L \\
(\mathrm{~mm})\end{array}$ & $\begin{array}{c}r \\
(\mathrm{~mm})\end{array}$ & $\begin{array}{c}t 1 \\
(\mathrm{~mm})\end{array}$ & $\begin{array}{c}t 2 \\
(\mathrm{~mm})\end{array}$ \\
\hline 1 & {$\left[15_{9} /-15_{9}\right]_{\mathrm{S}}$} & distributed & 30.0 & 32.8 & 1.125 & 2.250 \\
2 & {$\left[30_{9} /-30_{9}\right]_{\mathrm{S}}$} & distributed & 30.0 & 32.8 & 1.125 & 2.250 \\
3 & {$\left[45_{9} /-45_{9}\right]_{\mathrm{S}}$} & distributed & 30.0 & 32.8 & 1.125 & 2.250 \\
4 & {$\left[90_{8} / 0_{4}\right]_{\mathrm{S}}$} & distributed & 10.0 & 25.0 & 1.000 & 1.000 \\
5 & {$\left[90_{8} / 0_{4}\right]_{\mathrm{S}}$} & concentrated & 68.4 & 35.0 & 1.000 & 1.000 \\
6 & {$\left[0_{8} / 90_{4}\right]_{\mathrm{S}}$} & concentrated & 68.4 & 35.0 & 1.000 & 1.000 \\
\hline
\end{tabular}


第 3 表 CFRP 円筒モデルの材料特性

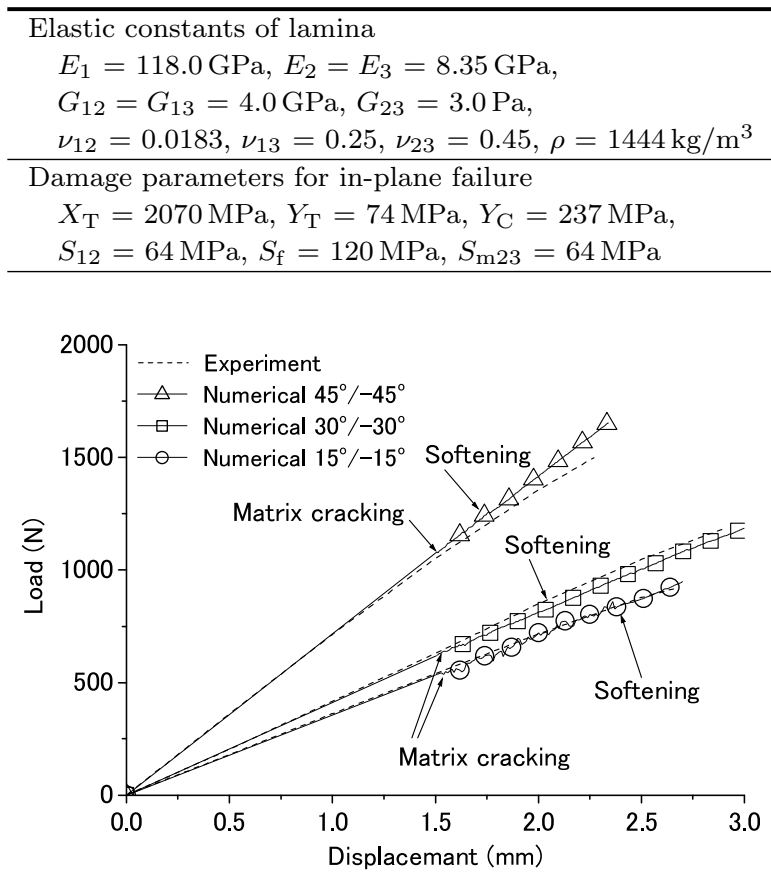

第 8 図 CFRP シェル解析結果, Case 1〜3

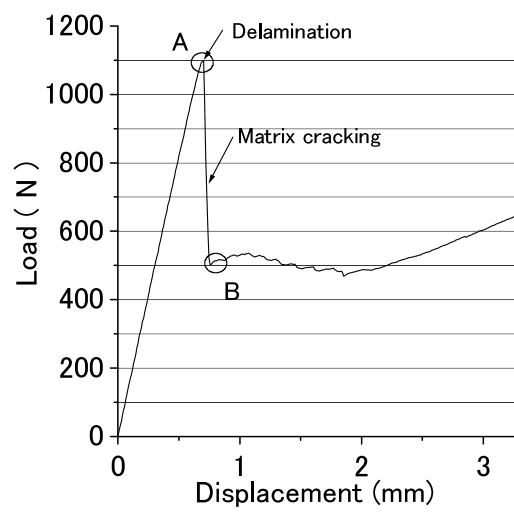

(a) 荷重履歴

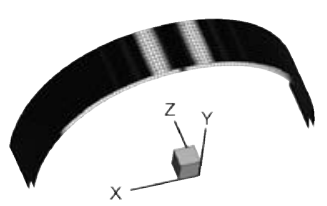

outside view

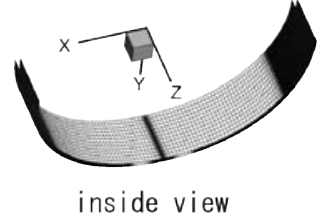

(b) はく離形状 (B 点)
第 9 図 CFRP シェル結果, 分布荷重 $\left(\left[90_{8} / 0_{4}\right]_{\mathrm{S}}\right.$ Case 4$)$

示す . 図中には面内破壊と，はく離の初期段階である軟化 の開始点を記した . 各積層構成において, 荷重点の内側に おいて軽微なマトリックスクラックが発生し, 弚の付近の 層間か軟化を始める . マトリックスクラック及び層間はく 離は急速に進展するのではなく，荷重点付近から徐々に軟 化領域を拡大しながらコヒーシブ要素の岡性も徐々に低下 し荷重勾配が緩やかになる．また，繊維配向角が大きく剛 性の高い円筒ほど，より小さい変形ではく離が発生する傾 向がある. 弚こで, 第 9 図には Case $4,\left[90_{8} / 0_{4}\right]_{\mathrm{S}}$ の円筒 に同樣の分布荷重を載荷した結果を示す．この場合，岡性 が緩やかに低下するのではなく面内破壊が生じる前に A 点 で層間はく離が発生し，かつはく離は内側の層間に急速に 広がる (B 点) .これは実験值において繊維配向角が大きい モデルでは面内破壞が生じる前にはく離が発生したとする 考察と同樣の傾向である.なお，この結果から，数值安定

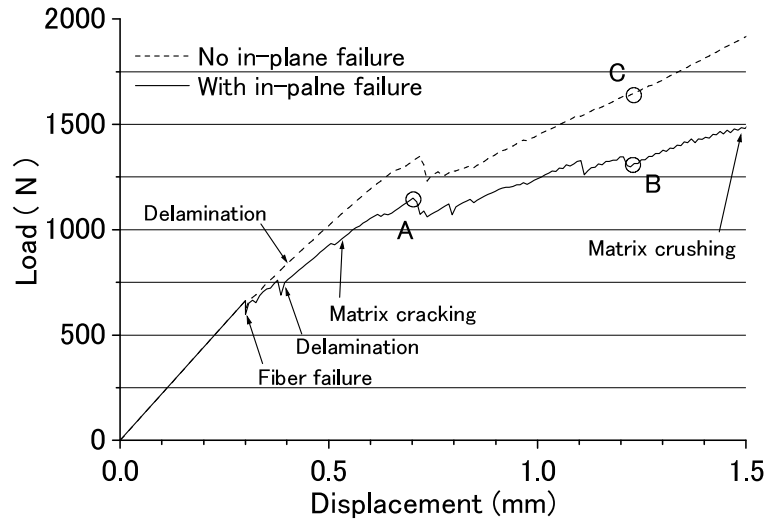

(a) 荷重履歴

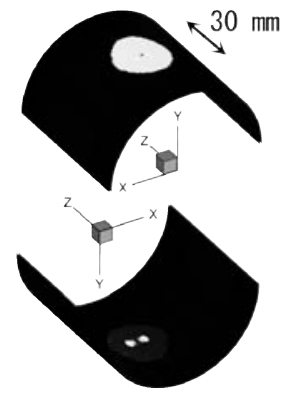

(b) はく離形状 (B 点)

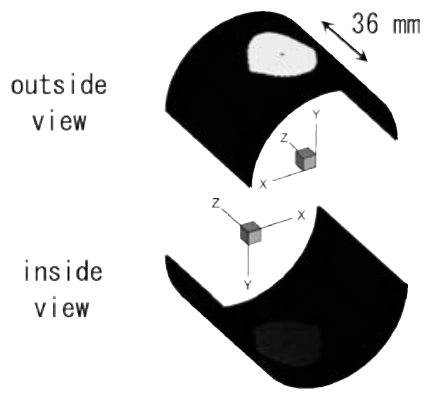

(c) はく離形状 ( $\mathrm{C}$ 点)
第10 図 CFRP シェル結果，集中荷重 $\left(\left[90_{8} / 0_{4}\right]_{S}\right.$ Case 5$)$

化のために導入した変位抑制効果は緩やかにはく離進展す る場合だけでなく，急激に進展するはく離についても損傷 を妨げることなく適用できることが分かる．

4.2 集中荷重下の損傷進展解析 次に集中荷重下を載 荷した場合の CFRP 円筒の解析例を示す.第 7 图に示した モデルに対し，積層構成は第 2 表の Case 5,6 の $\left[90_{8} / 0_{4}\right]_{\mathrm{S}}$ 及び $\left[0_{8} / 90_{4}\right]_{\mathrm{S}}$ ，対称性を考慮して $1 / 8$ モデルで解析を行 う. 要素サイズは荷重点から $45^{\circ}$ の範囲で周方向約 $1.8 \mathrm{~mm}$, $45^{\circ}$ 以降て約 $3.6 \mathrm{~mm}, Z$ 方向は荷重点から $18 \mathrm{~mm}$ の範囲 で $1.8 \mathrm{~mm}$, 弚れ以降は $5.4 \mathrm{~mm}$, いずれも厚さ方向には各 層で 1 分割である. 各材料定数は第 3 表と同樣とする . ま た，面内破壊が層間はく離に及ぼす影響を見るため，層間 はく離と面内破壞すべての破壞モードを考慮した解析と， 層間はく離だけを考慮した解析を行った .

$\left[90_{8} / 0_{4}\right]_{\mathrm{S}}$, Case 5 の結果を第 10 図に示す. 図中に示し た各破壤モードは光の損傷が生じ始めた箇所を示しており， 一度損傷が生じると光の後は断続的に発生する . 面内破壤 を考慮した場合，最初に荷重点で小さな繊維破断が生じ外 側の層間が緩やかに軟化を始める .この損傷によって岡性 が低下し，荷重勾配は緩やかになる．次にマトリックスク ラックか荷重点の内側に少しずつ生じ始めると，内側の層 間にもはく離が発生する . 約 $1100 \mathrm{~N}$ に到達するまでは外側 及び内側の層間ともにはく離の進展は緩やかであるが，A 点を過ぎると面内破壊を繰り返しながら急速にはく離面積 を拡大し，荷重勾配もさらに緩やかになる．また，同じ荷 重点変位 $(\mathrm{B} \cdot \mathrm{C}$ 点) においては面内破壊を考慮しない方 


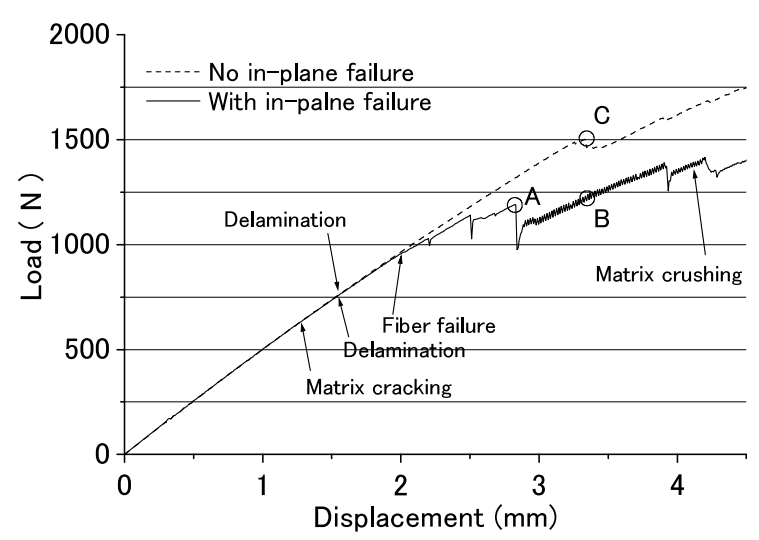

(a) 荷重履歴

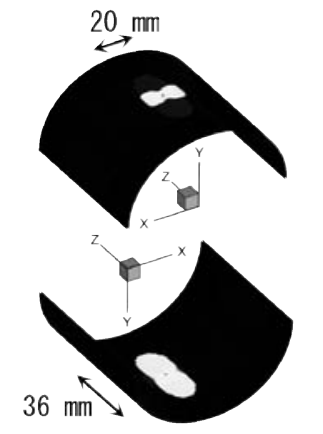

(b) はく離形状 (B 点)

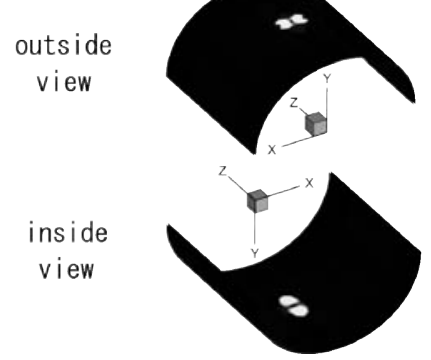

(c) はく離形状 ( $\mathrm{C}$ 点)
第11図 CFRP シェル結果，集中荷重 $\left(\left[08 / 90_{4}\right]_{\mathrm{S}}\right.$ Case 6$)$

が外側のはく離面積は大きく，内側のはく離はほとんど発 生しない，これは，面内破壊による岡性低下がないため荷 重が大きいこと，及び内側にマトリックスクラックが生じ ないと内側のはく離は発生しにくく, 主に外側の層間はく 離に対して仕事が費やされるためと考えられる .

$\left[0_{8} / 90_{4}\right]_{\mathrm{S}}$ ，Case 6 の結果を第 11 図に示す . 面内破壊を 考慮した場合，まず荷重点内側にマトリックスクラックが 生じ, 続いて外側及び内側の層間で小さいはく離が発生す る. 弚の後荷重点で小さい繊維破断を生じながら，ゆっく りとはく離が進展する.荷重が $1200 \mathrm{~N}$ ( A 点) に到達す るまでは, はく離の進展が緩やかなため荷重勾配の低下も 緩やかであるが，弚れを過ぎると主に内側の層間で急速に はく離面積を拡大し荷重勾配はさらに緩やかになる．また， 同じ荷重点変位 $(\mathrm{B} \cdot \mathrm{C}$ 点) においては, はく離の形状は いずれも板モデルとほぼ同樣のピーナッツ状に近いはく離 形状であるが, 面内破壞を考慮した方が考慮しない場合に 比へてて特に内側のはく離面積が大きい．これは， $\left[0_{8} / 90_{4}\right]_{\mathrm{S}}$ のモデルでは構造全体の変形が大きく, 一番内側の $0^{\circ}$ 層に 曲げによるマトリックスクラックが進展しやすいことが要 因と考えられる.一番内側の $0^{\circ}$ (繊維方向は $Z$ 軸方向) $の$ 層には, 曲げによるマトリックスクラックが , 中央から緎 維方向に沿って円筒端部にまて到達する直線状に発生して いる . この内側 $0^{\circ}$ 層の曲げクラックによって一番内側の層 は大きく曲げ変形を生じ, 中央 $90^{\circ}$ 層と一番内側 $0^{\circ}$ 層の 相対変位か増加するため, 内側の層間ではく離が大きく進 展している。
これらの結果から，はく離形状やはく離の大きさは面内 破壞の発生が大きく寄与していることが分かる . はく離は 面内破壊か甡じなくても発生, 進展するが, 面内破壞によっ てはく離が誘発あるいは進展が早まることが分かる．これ は面内破壞による剛性の低下によって, 付近のコヒーシブ 要素の有効変位が大きくなり, より低い荷重でもはく離が 進展しやすくなるためと考えられる．また，本解析モデル によって面内破壊と層間はく離が相互に及ぼす影響も再現 できていることが分かる .

\section{5. 結言}

本研究では, 纎維破断, マトリックスクラック, マトリッ クス圧縮破壞などの面内破壊と層間はく離といった積層構 造の主要な破壞モードをすべて考慮した三次元解析モデル を提案した . 面内破壊については応力破壞基準を用い, 中 央差分法に適用するための詳細な手法を示した . また，層 間はく離についてはコヒーシブ要素を用いる上で問題とな る数値不安定性に対して, 既に筆者らが提案した变位抑制 効果を採用し，この手法が面内破壊とともに混合モードで はく離する場合においても適用できることを示した .

これによって，従来要素サイズを非常に細かくしなけれ ば対応できなかった損傷進展解析を, 計算コストを増大さ せることなく安定して解析することが可能となり，板及び シェルといった樣々な構造形状に対し全破壞モードを考慮 した複雑な損傷進展を予測することが可能となった .

なお，本研究では準静的問題での損傷進展予測について 検討したが，運動エネルギーの増分を考慮した適切な変位 抑制幅の見積もりは困難であるため，準静的に限らず衝撃 荷重下で適用可能な数值安定化手法に発展させることが今 後の課題である .

\section{参 考 文 献}

1) Chang, F. and Chang, K.: A Progressive Damage Model for Laminated Composites Containing Stress Concentrations, J. Compos. Mater., 24 (1987), pp. 834-855.

2) Hou, J. P., Petrinic, N., Ruiz, C. and Hallett, S. R.: Prediction of Impact Damage in Composite Plates, Compos. Sci. Technol., 60 (2000), pp. 273-281.

3) Brewer, J. C. and Lagace, P. A.: Quadratic Stress Criterion for Initiation of Delamination, J. Compos. Mater., 22 (1988), pp. 1141-1155.

4) Davies, G. A. O. and Zhang, X.: Impact Damage Prediction in Carbon Composite Structures, Int. J. Impact Eng., 16 (1995), pp. 149-170.

5) Kamiya, S., Sekine, H. and Yagishita, Y.: Computational Simulation of Interlaminar Crack Extension in Angle-Ply Laminates Due to Transverse Loading, J. Compos. Mater., 32 (1998), pp. 744-765.

6) Camanho, P. P. and Davila, C. G.: Mixed-Mode Decohesion Finite Elements for the Simulation of Delamination in Composite Materials, NASA/TM-2002-211737, 2002, pp. 1-37.

7) Goncalves, J. P., de Moura, M. F., de Castro, P. T. and Marques, A. T.: Interface Element Including Point-toSurface Constraints for Three-Dimensional Problems with Damage Propagation, Eng. Comput., 17 (2000), pp. 28-47.

8) Mi, Y., Crisfield, M. A. and Davis, G. A. O.: Progressive Delamination Using Interface Element, J. Compos. Mater., 32 (1998), pp. 1246-1272. 
9) 間島 理, 末益博志 : 複合材料積層板中の多重層間はく離伝播挙 動の非線形有限要素解析, 日本複合材料学会誌, 26 (2000), pp. 219-226.

10) Majima, O. and Suemasu, H.: An Interface Element with Continuous Traction to Analyze Delamination Propagation, Adv. Compos. Mater., 14 (2005), pp. 165-179.

11) Gao, Y. F. and Bower, A. F.: A Simple Technique for Avoiding Convergence Problems in Finite Element Simulations of Crack Nucleation and Growth on Cohesive Interfaces, Modelling Simul. Mater. Sci. Eng., 12 (2004), pp. 453-463.

12) 前場 豊, 胡寧, 福永久雄 : コヒーシブ要素を用いた層間は 〈離シミュレーションにおける数值安定化, 日本複合材料学会誌, 32 (2006), pp. 67-75.

13) Zuo, Q. H., Addessio, F. L., Dienes, J. K. and LewisReddy, M. W.: A Rate-Dependent Damage Model for Brittle Materials Based on the Dominant Crack, Int. J. Solid Struct., 31 (1997), pp. 812-831.

14) Soo, A. L., Aspinwall, D. K. and Dewesa, R. C.: 3D FE Modelling of the Cutting of Inconel 718, J. Mater. Proc. Technol.,
150 (2004), pp. 116-123.

15) Reddy, Jr. E. D., Mello, F. J. and Guess, T. R.: Modeling the Initiation and Growth of Delaminations in Composite Structures, J. Compos. Mater., 31 (1997), pp. 812-831.

16) Cao, Y. P., Hu, N., Lu, J., Fukunaga, H. and Yao, Z. H.: A 3D Brick Element Based on $\mathrm{Hu}$-Washizu Variational Principle for Mesh Distortion, Int. J. Numer. Eng., 53 (2002), pp. $2529-2548$.

17) Shi, Y. B., Hull, D. and Price, J. N.: Mode II Fracture of $+\theta /-\theta$ Angled Laminate Interfaces, Compos. Sci. Technol., 47 (1993), pp. 173-184.

18) Hwu, C., Kao, C. J. and Chang, L. E.: Delamination Fracture Criteria for Composite Laminates, J. Compos. Mater., 29 (1995), pp. 1962-1987.

19) Nishiwaki, T., Yokoyama, A., Maekawa, Z., Hamada, H. and Mori, S.: A Quasi-Three-Dimensional Lateral Compressive Analysis Method for a Composite Cylinder, Compos. Struct., 32 (1995), pp. 293-298. 